\title{
INFLUENCE OF SURGICAL TECHNIQUE IN THE PERITONEAL CARCINOMATOSIS SURGICAL WOUND IMPLANT: EXPERIMENTAL MODEL IN MICE
}

Influência da técnica cirúrgica na implantação da carcinomatose peritoneal em ferida operatória: modelo experimental em camundongos

\author{
Roberto Maranhão ROSA, Rafael Coelho CAIADO, Paulo Roberto de Melo REIS, \\ Elisângela de Paula Silveira LACERDA, Denis Masashi SUGITA, Fátima MRUÉ
}

From the Laboratório de Estudos Experimentais e Biotecnologia, Campus II, Pontifícia Universidade Católica (Experimental and Biotechnology Studies Laboratory, Campus II, Catholic University), Goiânia, Goiás, Brazil.
ABSTRACT: Background: The number of malignancies increased alarmingly. Surgery constitutes one of the most efficient therapeutic modalities for the treatment of solid tumors. The neoplastic implant in surgical wound is a complication whose percentage of occurrence reported in the literature is variable, but sets with high morbidity and therapeutic difficulties. Protecting the wound is one of the recommended principles of oncologic surgery. Aim: To evaluate the influence of wound protection in the development of tumor implantation. Methods: Sarcoma 180 tumor cells were used, with intraperitoneal inoculation in Swiss mice. After the establishment of neoplastic ascites, animals were randomized into two groups of 10, each group consisting of five males and five females. In both groups, laparotomy and manipulation of intra-abdominal organs was performed. In a group laparotomy was performed using the protection of the abdominal wound and the other group without it. On the $9^{\text {th }}$ postoperative day macroscopic evaluation of the operative scar was performed, which was later removed for microscopic evaluation. Results: There was microscopic infiltration of tumor cells in the wound of all animals. However, the group that held the protection, infiltration was less intense when compared to the group without it. The infiltration was also more severe in females than in males of the same group. Conclusion: Tumor infiltration into the wound was more intense in the group in which the protection of the surgical site was not performed, and in females when compared to males of the same group.
HEADINGS - Ascites. Sarcoma 180 Models, Animal.
RESUMO: Racional: O número de neoplasias vem aumentando de maneira preocupante. O tratamento cirúrgico constitui-se em uma das modalidades terapêuticas mais eficientes para os tumores sólidos. O implante neoplásico em ferida operatória é complicação cujo percentual de ocorrência relatado na literatura é variável, porém configura alta morbidade e grande dificuldade terapêutica. A proteção da ferida operatória é um dos princípios de cirurgia oncológica recomendados, entretanto pouco estudado. Objetivo: Avaliar a influência da proteção de ferida operatória no desenvolvimento de implante tumoral na ferida operatória. Métodos: Foram utilizadas linhagens de células tumorais do Sarcoma 180, com inoculação intraperitoneal em camundongos Swiss. Após o estabelecimento da ascite neoplásica, os animais foram randomizados em dois grupos de 10, cada grupo composto por cinco machos e cinco fêmeas. Nos dois grupos foi realizada laparotomia e manipulação de órgãos intraabdominais. Em um grupo a laparotomia foi realizada utilizando a proteção da ferida abdominal e no outro grupo sem proteção. No $9^{\circ}$ dia pós-operatório foi realizada avaliação macroscópica da cicatriz operatória, sendo esta removida posteriormente para avaliação microscópica. Resultados: Houve infiltração microscópica de células tumorais na ferida operatória em todos animais. Porém, no grupo em que se realizou a proteção da ferida a infiltração foi menos intensa quando comparado ao grupo sem proteção. A infiltração também foi mais intensa nas fêmeas do que nos machos do mesmo grupo. Conclusão: A infiltração tumoral na ferida operatória foi mais intensa no grupo em que não foi realizada a proteção da ferida operatória e nas fêmeas quando comparadas aos machos do mesmo grupo.
$\mathrm{S}$ urgery is one of the oldest therapeutic modalities for cancer treatment. It is also the most widely used method of addressing all stages of the disease.

In Brazil, the number of oncological operations in 2012 was 86,104 and in the Midwest region $5.432^{2}$; there is an estimated increase in the number in $24 \%$ by the year $2020^{4}$

The implant of neoplastic cells in surgical wounds always constituted concern due to the high morbidity that entails. The implant may occur in operations performed by conventional means of access, or "open", as well as those performed by minimally invasive means, which are mainly the laparoscopic, video-assisted thoracoscopic, among others. The neoplastic implantation in the portals access 
of these operations - also known by some as "port-site metastasis" -, has become an important focus of attention due to increased use of laparoscopy in oncology in recent decades. For some authors, the implants incidences range from $0.62-3.9 \%$ in portals for colorectal carcinoma, $1-16 \%$ for ovarian carcinoma and $14-32 \%$ for gallbladder cancer $^{1,11,12}$. Port site metastasis are defined as recurrent cancer lesions that develop locally in the abdominal wall, inside the scar tissue and at one or more trocar sites ${ }^{3}$, which may occur similarly in portals using locations other than the abdomen.

In previous studies, several models have been proposed to explain the cause of this type of neoplastic implantation: the direct implantation in wound contaminated by surgical instruments; tumor cell aerosolization; chimney effect; tumor excessive manipulation; pneumoperitoneum; hematogenous spread; local and systemic pneumoperitoneum effects due to carbon dioxide; surgical technique and tumor aggressiveness ${ }^{3}$. Although the last one is probably the most important factor, inadequate surgical technique associated with traumatic tumor manipulation are the risk factors over which surgeons can have more control ${ }^{15}$.

The adequacy of animal models used in preclinical studies directly influences the quality of these studies, as well as in the correct application and success of clinical trials subsequently done ${ }^{7}$.

In oncology, currently, there are several experimental models that may help to clarify this form of dissemination. Among the most used in mice, stands out Sarcoma 180 or Crocker tumor, undifferentiated tumor found in male albinus rats in 1914. This tumor was classified as primarily breast carcinoma, but after multiple subcutaneous transplantation, it was observed that their morphological characteristics and behavior were characteristic of a sarcoma and then began to be called Sarcoma $180^{14}$. It is a cell line transplanted subcutaneously, intramuscularly or intraperitoneally, growing rapidly at $90 \%$ to $100 \%$ of the inoculated animals ${ }^{9}$.

Nevertheless, there are some conditions that favor the use of transplantable tumors in experiments producing ascites, such as the ease of standardization of the number of cells to be inoculated; quantification of growth and regression of the tumor mass; possibility to carry out a comparative study, using the same methods into bloodstream and corporal fluids ${ }^{8}$. To evaluate the implant of neoplastic cells in surgical wounds, the model of neoplastic ascites and sham, with opening and closing the cavity, is attractive experimental model due to the speed of tumor development, simplicity of procedures, and causing less suffering to animals.

The objective of this study was to evaluate the influence of wound protection in the development of neoplastic implantation.

\section{METHODS}

All experimental procedures in this study were approved by the Ethics Committee on Animal Use at PUC-Goiás in accordance with Law 11,794/2008 (Arouca Law), which establishes procedures for the scientific use of animals in research and graduate education in the country.

Were used 24 Swiss mice of both sexes, aged 6-8 weeks and weighing between 29.5 to $39.6 \mathrm{~g}$. The animals were kept with a standard commercial diet and water ad libitum, and light-dark cycle of $12 \mathrm{~h}$.

For the induction of ascites in the animal model was used tumor lineage of Sarcoma 180. The cells were kindly provided by the Molecular Genetics and Cytogenetics Laboratory of the Federal University of Goiás, Goiânia, GO, Brazil. The cell line was maintained in two Swiss mice, as source animals, through successive intraperitoneal passages in the amount of $2 \times 10^{6}$ cells adjusted to final volume of $0.2 \mathrm{ml}$. After a period of seven days of tumor inoculation they were sacrificed, the peritoneal cavity fluid was aspirated, cells were washed in phosphate buffered saline solution and an aliquot of the cell suspension was added to trypan blue dye (1\% w/v) (Sigma-Aldrich Corp. St. Louis, MO). The solution was then quantified in a Neubauer chamber and only dilutions cell with viability $\geq 90 \%$ were used for in vivo studies ${ }^{10}$.

Subsequently, all animals received intraperitoneally in the right lower abdomen, injection with $5 \times 10^{5}$ cells per animal, totaling volume of $0.2 \mathrm{ml}$ of Sarcoma 180 tumor cells.

After nine days period, the mice were then randomly assigned into two groups of 10, containing five males and five females in each group. Was named group 1 , the one that was operated with surgical wound protection technique, and group 2, which was operated without it. The animals in each group were subdivided as follows: group 1, males named as "male with wound protection" (CPM) and numbered 1-5, and as well as in females (CPF) of the same group; group 2, used the term "wound without protection for males" (SPM) and "wound without protection for females"(SPF), followed by the number 1 to 5 .

\section{Anesthesia}

The animals were anesthetized as recommended for weight, using Thiopental anesthetics, ketamine hydrochloride $100 \mathrm{mg} / \mathrm{ml}$, xylazine $20 \mathrm{mg} / \mathrm{ml}$ and acepromazine maleate $10 \mathrm{mg} /$ diluted in sterile water and used at a dose of $125-150 \mathrm{mg} / 100 \mathrm{~g}$ body weight. Anesthesia was performed by veterinary professional, team member.

\section{Surgical procedure}

Was carried out in aseptic conditions and adequate antisepsis and trichotomy performed by appropriate equipment for hair removal.

In group 1, the animals were submitted to the opening of the abdominal cavity by midline incision, by planes, being held small incision in the peritoneum, aspiration of ascites, which was sent to cell count. After complete aspiration of ascites, the incision was enlarged to approximately $2 \mathrm{~cm}$ long and made the protection of the wound edges with secondary surgical drapes. In group 2, the animals were submitted to the opening of the abdominal cavity by midline incision, by planes, in length of approximately $2 \mathrm{~cm}$. After the opening of the cavity, in both groups was made manipulation of the organs of the abdominal cavity for $2 \mathrm{~min}$ and then held the closure of the cavity by planes: peritoneum and aponeurosis, single layer, using a single running suture with 3-0 Vycril ${ }^{\circledR}$ and skin with simple running suture with 4-0 nylon and dressing.

\section{Observation period and variables analysis}

The animals were observed daily by clinical examination of the wound to the development of the implant. The examination was held at the time of euthanasia, using inspection and palpation of the skin surface of the wound and inspection of the peritoneal surface.

Microscopic examination of the surgical wound was made by histological sections of the wound using hematoxylin\&eosin. Subsequently, evidence 
of the presence of neoplastic cells in the ascites was performed using cytology with Papanicolaou staining, hematoxylin\&eosin and PAS.

\section{Euthanasia procedure}

The animals were anesthetized as described for the surgical procedure, and after removal of the surgical specimen (wound), they were led to deep plane by Thiopental sodium administration. Subsequently, when the clinical signs shown deep anesthesia, was then administered by intra-cardiac route, $10 \%$ potassium chloride solution.

\section{RESULTS}

At the beginning of the experiment the average weight of the animals was $35.28 \mathrm{~g}$ for male and $35.28 \mathrm{~g}$ for females. At the end, there was no significant weight difference regarding the wound protection; however, there was a greater weight gain in females compared to males.

Most of the animals developed ascites with gelatinous appearance and growth of tumor cells in the peritoneal fluid was observed in $100 \%$ of which was confirmed by cytology, validating the model.

The surgical procedure was performed using surgical wound protection technique with gauze at the edges, avoiding contact of ascites with them, and the technique performed without protection, without the aid of protective gauze, allowing ascites liquid contact (Figure 1).

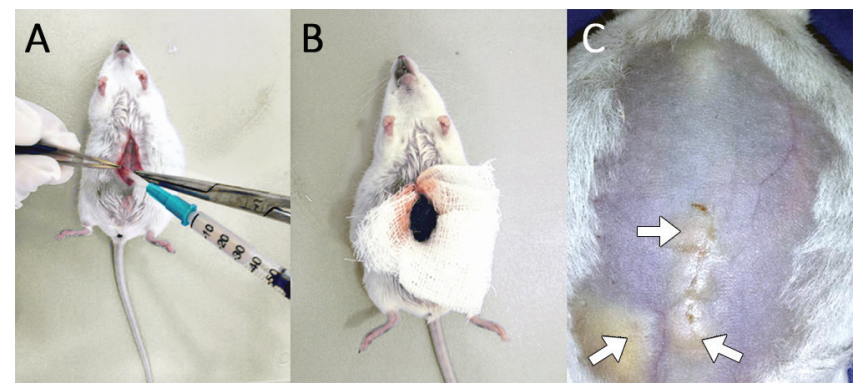

FIGURE 1 - A) Peritoneum opening followed by aspiration of ascites; B) wound with edge protection; C) surgical scar with cutaneous nodules (arrows), also can be observed tumor implant at the site of initial inoculation in the right iliac fossa (arrow)

After eight days following the group of male mice in which was performed surgical wound protection, clinically showed no neoplastic implantation in the surgical wound, while two of the four females presented. One of the females in this group was found dead with no apparent cause, before the end of the planned observation period. In the group where there was no wound protection, three of the five males developed neoplastic implantation in the wound, while among the five females, four had it clinically visible (Figure 2, Table 1).
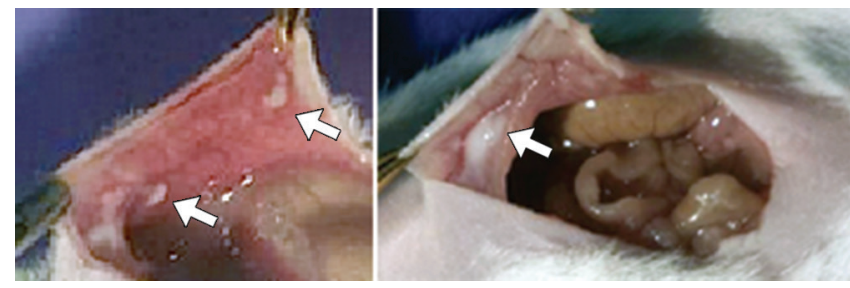

FIGURE 2 - Peritoneal nodules on the left (arrows) and intramural on right (arrow)
TABLE 1 - Gross evaluation of neoplastic implantation on surgical wound, according to the surgical technique and sex

\begin{tabular}{|c|c|c|c|c|}
\hline & \multicolumn{2}{|c|}{ WITHOUT PROTECTION } & \multicolumn{2}{|c|}{ WITH PROTECTION } \\
\hline SEX & ID & IMPLANT & ID & IMPLANT \\
\hline \multirow{5}{*}{ FEMALES } & SPF1 & YES & CPF1 & YES \\
\hline & SPF2 & YES & CPF2 & YES \\
\hline & SPF3 & NO & CPF3 & NO \\
\hline & SPF4 & YES & CPF4 & NO \\
\hline & SPF5 & YES & & \\
\hline \multirow{5}{*}{ MALES } & SPM1 & NO & CPM1 & NO \\
\hline & SPM2 & YES & CPM2 & NO \\
\hline & SPM3 & NO & CPM3 & NO \\
\hline & SPM4 & YES & CPM4 & NO \\
\hline & SPM5 & YES & CPM5 & NO \\
\hline
\end{tabular}

$\mathrm{CPM}=$ males numbered $1-5$ with wound protection; $\mathrm{CPF}=$ females with wound protection; $\mathrm{SPM}=$ males without wound protection; $\mathrm{SPF}=$ females without wound protection

For microscopic analysis, all animals showed neoplastic implantation in the surgical wound, regardless of group. However, there was a difference in the intensity of neoplastic infiltration between groups, becoming more intense in the group without protection, then on the group of females with wound protection (Figure 3, Table 2).
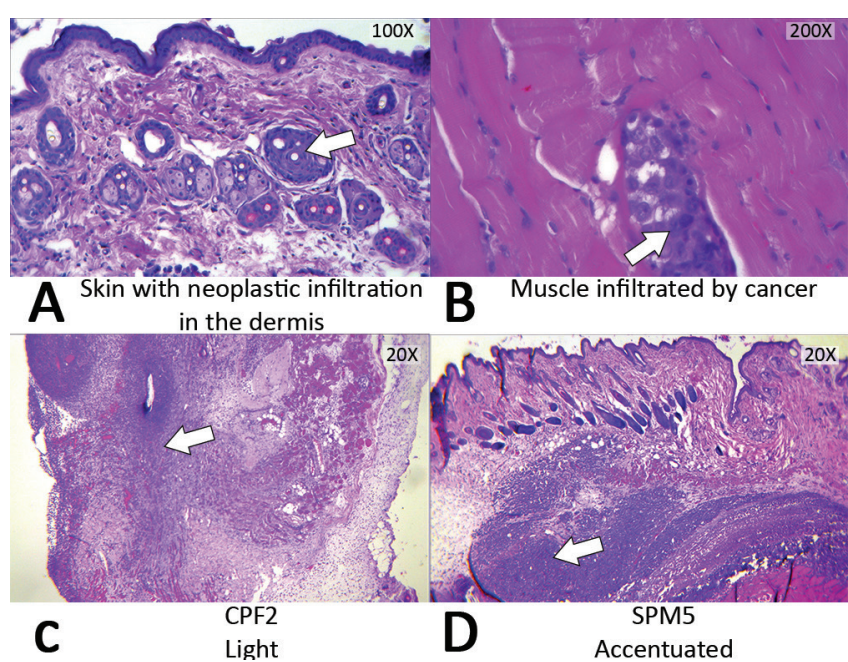

FIGURE 3 - Microphotography of histological section of wound, in which can be observed in A and B neoplastic cells infiltrating the abdominal wall (arrows); C and D the intensity of neoplastic infiltration (arrow)

TABLE 2 - Intensity of microscopic neoplastic infiltration of the surgical wound, according to the surgical technique and sex

\begin{tabular}{c|c|c|c|c|}
\hline & \multicolumn{2}{c}{ WITHOUT PROTECTION } & \multicolumn{2}{c}{ WITH PROTECTION } \\
\hline \multirow{4}{*}{ SEX } & ID & INTENSITY & ID & INTENSITY \\
\hline \multirow{5}{*}{ FEMALE } & SPF1 & +++ & CPF1 & +++ \\
\cline { 2 - 6 } & SPF2 & +++ & CPF2 & +++ \\
& SPF3 & ++ & CPF3 & ++ \\
& SPF4 & ++ & CPF4 & ++ \\
& SPF5 & +++ & CPF5 & \\
\cline { 2 - 5 } MALE & SPM1 & +++ & CPM1 & +++ \\
& SPM2 & ++ & CPM2 & ++ \\
& SPM3 & ++ & CPM3 & ++ \\
& SPM4 & +++ & CPM4 & + \\
& SPM5 & +++ & CPM5 & +++ \\
\hline
\end{tabular}

light: + ; moderate: ++ ; severe: $+++; \mathrm{CPM}=$ males numbered $1-5$ with wound protection; $\mathrm{CPF}=$ females with wound protection; $\mathrm{SPM}=$ males without wound protection; $\mathrm{SPF}=$ females without wound protection 
Cancer is common disease; in 2012 there were 14.1 million new cases in the world, with $57 \%$ of them among the least developed countries ${ }^{16}$. Tumor dissemination process is complex; occurs in multiple stages and has not yet been completely elucidated. The body homeostasis process and the balance of the immune system, influence the process of carcinogenesis and tumor progression; this influence was identified in 1863 by Rudolf Virchow ${ }^{5}$.

In the present study was observed microscopic involvement by tumor cells in the surgical scar in all animals. In the group in which the wound protection was not performed, this commitment was intense and occurred in all animals. Surprisingly, the group that held the wound protection, macroscopically only two of the nine cases were suspected of tumor involvement; however, microscopically the nine cases had tumor cell infiltration in the surgical scar. Several authors point out possible influence of sex hormones in the development and cancer progression ${ }^{13}$. In this study it was observed that the intense involvement of the surgical wound was higher in females than in males, with macroscopic suspicion of involvement in $50 \%$ of cases that held wound protection, while in the group of males with protection wound there was no macroscopic suspected compromise.

Although with few reports, tumor implantation in surgical scar is highly morbid and should be avoided by technical measures. The ascites tumor model is useful for the study of the influence of the surgical technique in the prevention and development of neoplastic implantation. Among them, the Crocker tumor model is important in providing development of neoplastic ascites seven to ten days after inoculation and is effective in over $70 \%$ of the animals. In the present study the establishment of neoplastic ascites occurred in all animals, demonstrating the effectiveness of this experimental model. The evaluation period of this study only included the initial phase of wound healing process, which may explain in part the presence of tumor cells in low intensity in the group with wound protection.

Based on this study it's not possible to understand the tumor progression sufficiently to establish the exact way of scar implant, and the influence of the wound protection. In this group, the presence of tumor cells in low intensity, is not sufficient to conclude definitively on tumor implant, because the wound healing process was not yet completed. During the healing process, body homeostasis and tissue regeneration use the various cellular and humoral defense mechanisms, which may occur during this process to destroy any local cancer cells $s^{6}$. Based on this study, it can be concluded that there was more intense infiltration of neoplastic cells in the wound in the group without wound protection in relation to the group that wound protection was performed. Similarly, neoplastic infiltration was more pronounced in females than in males. It is believed that this study may contribute to better understanding of neoplastic invasion process in surgical situations, as well as can contribute to confirm the establishment of surgical oncology principles. However, for further and comprehensive understanding of the subject, there is need for further studies covering different stages of healing and different tumor models.
The tumor infiltration in the surgical wound was more intense in the group where the wound protection was not performed. However, microscopic neoplastic infiltration occurred in all animals, regardless of wound protection. Females compared to males of the same group showed higher intensity to infiltration, regardless of the group they belonged to.

\section{REFERENCES}

1. Azevedo JLMC, Mattos D, Azevedo O. Descoberta simultânea de carcinomatose disseminada e carcinoma de cólon, após colecistectomia laparoscópica. Rev Col Bras Cir. 2000;27(4):284-286.

2. Brasil. Ministério da Saúde. Sistema de Informações Hospitalares do SUS (SIH-SUS). Disponível em: http://tabnet.datasus.gov.br/cgi/ tabcgi.exe?sih/cnv/qiuf.def. [Acessado em 10 de Jun. de 2014].

3. Chaturvedi S, Basal V, Kapoor R, Mandhani A. Is port site metastasis a result of systemic involvement? Indian J Urol 2012 Apr-Jun; 28(2): 169-73.

4. Devita VTJ, Hellman S, Rosenberg SA. Cancer: Principles and Practice of Oncology. In: Lippincott W, Wilkins. Principles of Surgical Oncology. 6th ed. Philadelphia, USA; 2008. P. 284-306.

5. Goel S, Duda DG, Xu L, Munn LL, Boucher Y, Fukumura D, Jain RK. Normalization Of The Vasculature For Treatment Of Cancer And Other Diseases. Physiol Rev 2011 July; 91(3): 1071-121.

6. Gupta P, Agarwal A, Gupta V, Singh PK, Pantola C, Amit S. Expression and Clinicopathological Significance of Estrogen and Progesterone Receptors in Gallbladder Cancer. Gastrointest Cancer Res 2012 Mar-Apr; 5(2):41-7.

7. Hossne RS. Tumor hepático experimental (VX-2) em coelho: implantação do modelo no Brasil. Acta Cir Bras 2002 Ago; 17(4): 208-10.

8. Nery LHR. Eficácia da dexametasona e da doxorrubicina no tumor de Ehrlich transplantado em camundongos BALB/c. [Tese] Programa de Pós Graduação em Medicina Veterinária. Universidade Federal de Viçosa, Minas Gerais, Brasil. 2004. 71 pgs.

9. Oliveira-Jr JR, Cheschini JJ, Humanes AC, Morelli S, Silveira-Lacerda EP. Caracterização citogenética de uma linhagem celular tumoral (Sarcoma 180) de Mus Musculus. In: $51^{\circ}$ Congresso Brasileiro de Genética - 2005 - São Paulo, Brasil.

10. Qi L, Xu Z. In vivo antitumor activity of chitosan nanoparticles. Bioorganic Med Chem Letters 2006 Aug; 16(16): 4243-5.

11. Ribeiro-Junior U, Leonardi PC, Melo GR, Pollara WM, Cecconello I. Método laparoscópico no diagnóstico e extensão da carcinomatose peritoneal. Arq Bras Cir Dig. 2010;23(3):196-199.

12. Santana KM, Leite RCBO. Complicações da videocirurgia para pacientes oncológicos. Rev Bras Cancerol 2006 Nov; 52(1): 79-86.

13. Sharma S, Eghbali M. Influence of sex differences on microRNA gene regulation in disease. Biology of Sex Differences [serial online]. 2014, Fev. [Acessado em 4 de Jun. de 2014]; (5)3: pp. 1-8. Disponível em: http://www.bsd-journal.com/content/5/1/3

14. Silva $A E$, Santos FGA, Cassali GD. Marcadores de proliferação celular na avaliação do crescimento do tumor sólido e ascítico de Ehrlich. Arq Bras Med Vet Zootec. 2006 Ago; 58(4): 658-61.

15. Sooriakumaran $\mathrm{P}$, Kommu SS, Anderson C, Rane A. Port-site metastasis after laparoscopic surgery: what causes them and what can be done to reduce their incidence? BJU International 2009 May; 103(9): 1150-53.

16. WHO. International Agency for Research on Cancer. Globocan 2012: Estimated Cancer Incidence, Mortality and Prevalence Worldwide 2012. Disponível em: http://globocan.iarc.fr/Pages/fact_sheets cancer.aspx. [Acessado em 10 de Jun. de 2014]. 